\title{
Corrigendum to "Intraspecific and Intracolonial Variation in the Profile of Venom Alkaloids and Cuticular Hydrocarbons of the Fire Ant Solenopsis saevissima Smith (Hymenoptera: Formicidae)"
}

\author{
Eduardo Gonçalves Paterson Fox, ${ }^{1}$ Adriana Pianaro, ${ }^{2}$ Daniel Russ Solis, ${ }^{3}$ \\ Jacques Hubert Charles Delabie, ${ }^{4}$ Bruno Cunha Vairo, ${ }^{5}$ \\ Ednildo de Alcântara Machado, ${ }^{1}$ and Odair Correa Bueno ${ }^{3}$ \\ ${ }^{1}$ Laboratório de Entomologia Médica e Molecular, Instituto de Biofísica Carlos Chagas Filho, \\ Universidade Federal do Rio de Janeiro (IBCCF/UFRJ), Rio de Janeiro, RJ, Brazil \\ ${ }^{2}$ Instituto de Quimica, Universidade Estadual de Campinas (IQ/UNICAMP), 13083-862 Campinas, SP, Brazil \\ ${ }^{3}$ Instituto de Biociencias, Universidade Estadual Paulista (UNESP), \\ Campus de Rio Claro and Centro de Estudos de Insetos Sociais (CEIS), 13506-900 Rio Claro, SP, Brazil \\ ${ }^{4}$ Laboratório de Mirmecologia, Centro de Pesquisas do Cacau (CEPLAC), Itabuna, BA, Brazil \\ ${ }^{5}$ Laboratório de Tecido Conjuntivo, Instituto de Bioquímica Médica, UFRJ, RJ, Brazil
}

Correspondence should be addressed to Eduardo Gonçalves Paterson Fox; ofoxofox@gmail.com

Received 14 July 2016; Accepted 17 October 2016

Copyright (C) 2016 Eduardo Gonçalves Paterson Fox et al. This is an open access article distributed under the Creative Commons Attribution License, which permits unrestricted use, distribution, and reproduction in any medium, provided the original work is properly cited.

In the article titled "Intraspecific and Intracolonial Variation in the Profile of Venom Alkaloids and Cuticular Hydrocarbons of the Fire Ant Solenopsis saevissima Smith (Hymenoptera: Formicidae)" [1], the method description was incomplete and inaccurate. Thus, the last part of the "2.4. GCMS Analyses" section "The injector temperature was $250^{\circ} \mathrm{C}$. Oven temperature was programmed to increase at $12^{\circ} \mathrm{C} / \mathrm{min}$ from $50^{\circ} \mathrm{C}$ to $330^{\circ} \mathrm{C}$, with a final hold time of $1 \mathrm{~min}$ " should be corrected to "The injector temperature was $250^{\circ} \mathrm{C}$. Oven temperature was programmed to increase at $12^{\circ} \mathrm{C} / \mathrm{min}$ from $50^{\circ} \mathrm{C}$ to $290^{\circ} \mathrm{C}$ with a hold pause for 6 minutes, followed by an increase of $30^{\circ} \mathrm{C} / \mathrm{min}$ from $290^{\circ} \mathrm{C}$ to $320^{\circ} \mathrm{C}$ followed by a final hold time of 1 min."

\section{References}

[1] E. G. P. Fox, A. Pianaro, D. R. Solis et al., "Intraspecific and intracolonial variation in the profile of venom alkaloids and cuticular hydrocarbons of the fire ant Solenopsis saevissima smith (Hymenoptera: Formicidae)," Psyche, vol. 2012, Article ID 398061, 10 pages, 2012. 



Submit your manuscripts at

http://www.hindawi.com
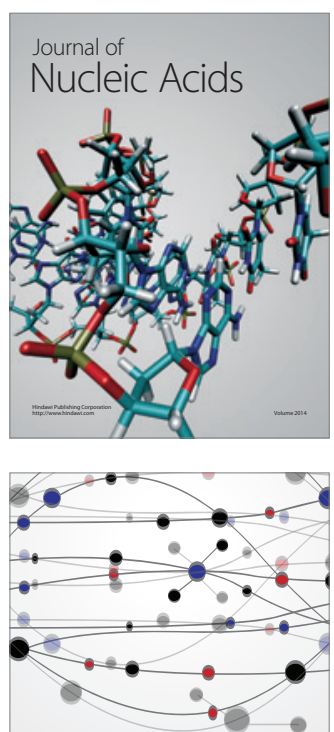

The Scientific World Journal
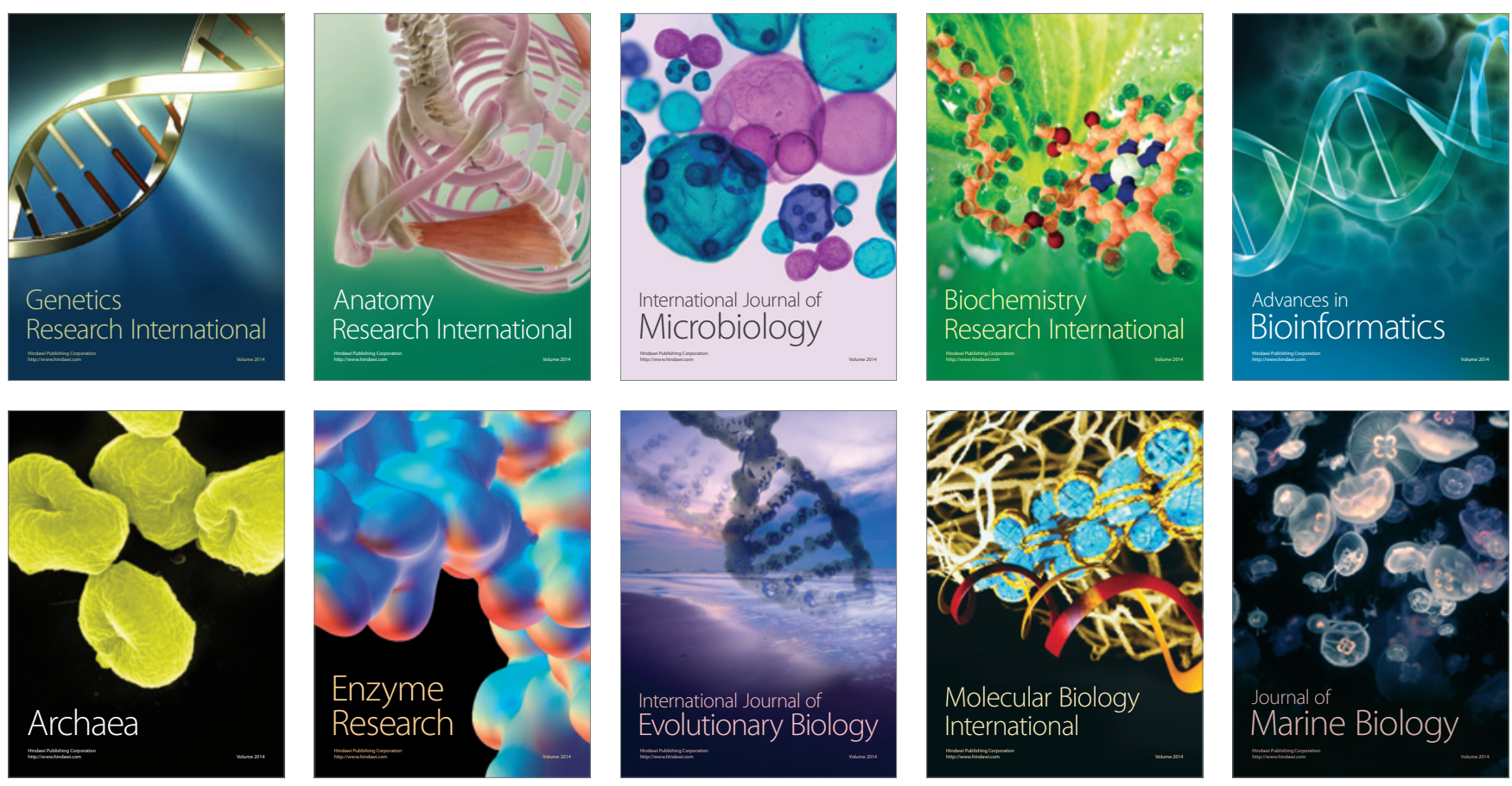